\title{
Chromosomic breaks and gaps in breast carcinomas of female dog
}

\author{
Canzoneri, R. ${ }^{1}$; Rosciani, A.S. ${ }^{2}$, Jorge, L.C. ${ }^{2}$ \\ ${ }^{1}$ Centro de Investigaciones Inmunológicas (CINIBA), Fac. Cs. Médicas Univ. Nac. La Plata (Argentina). \\ ${ }^{2}$ Fac. Cs. Veterinarias, Univ. Nac. Nordeste, Sargento Cabral 2139, Corrientes (3400), Argentina. \\ Tel.: 0054-0379-4425753, E-mail: liliancj@vet.unne.edu.ar.
}

\begin{abstract}
Canzoneri, R.; Rosciani, A.S.; Jorge, L.C.: Chromosomic breaks and gaps in breast carcinomas of female dogs. Rev. vet. 24: 2, 81-85, 2013. A cytogenetic study of canine breast carcinomas was performed in order to identify the occurrence of chromosomal abnormalities. Samples of spontaneous canine mammary tumors were submitted for histopathological evaluation and for cytogenetic analysis. Hematoxylin and eosin staining was used for the former and conventional Giemsa staining and NOR banding were performed for the latter. Chromosomal breaks and/or gaps affecting autosomes and sex chromosomes were seen in 5 of a total of 14 cases. The percentage of metaphases with abnormal chromosomes was $61 \%$, the average number of metaphase's chromosomes affected was 1.26 , while a media of 1.47 breaks and/or gaps was seen per metaphase. These alterations were observed in complex and simple carcinomas. We propose to include this type of cytogenetic study in addition to routine techniques in order to improve the diagnosis and prognosis prediction.
\end{abstract}

Key words: dog, mammary tumors, cytogenetic, fragile sites.

\begin{abstract}
Resumen
Canzoneri, R.; Rosciani, A.S.; Jorge, L.C.: Quiebres y gaps cromosómicos en carcinomas mamarios de hembras caninas. Rev. vet. 24: 2, 81-85, 2013. Se realizó un estudio citogenético de carcinomas de mama en hembras caninas con el fin de identificar la ocurrencia de anomalías cromosómicas. Las muestras se obtuvieron de neoplasias mamarias espontáneas y fueron sometidas a evaluación histopatológica y análisis citogenético. Para el primero se utilizó la tinción de hematoxilina y eosina y para el segundo la coloración convencional de Giemsa y bandeo NOR. En 5 oportunidades, de un total de 14 casos estudiados, se observaron quiebres y/o gaps afectando autosomas y cromosomas sexuales. La proporción de metafases verificada en cromosomas anormales fue de $61 \%$, el número promedio de cromosomas afectados por metafase fue de 1,26, mientras que la media de quiebres y/o gaps por metafases fue de 1,47. Estas alteraciones se observaron en carcinomas complejos y simples. Se propone incorporar este tipo de estudio citogenético a las técnicas de rutina con el fin de complementar el diagnóstico y pronóstico de la afección.
\end{abstract}

Palabras clave: perra, tumores mamarios, citogenética, sitios frágiles.

\section{INTRODUCTION}

Mammary tumors are the most frequent neoplasm in female dogs and approximately $50 \%$ of them are malignant. The risk of developing this disease increases with the age of the patients, being most common between the age of 9-10 years ${ }^{4,18}$. Tumors appear as single or multiple nodules in one or more mammary glands ${ }^{10}$. They are characterized for being of the same or different histological types, showing striking variable structures and unpredictable biological behavior ${ }^{11}$.

Recibido: 25 octubre 2012 / Aceptado: 6 marzo 2013

Presentado en Reunión SGCYT-UNNE 2010
On that basis many different parameters are taken into account to make a more accurate diagnosis and prognosis, like the presence of necrotic areas, vascular infiltration, dermis invasion and fundamentally, the realization of histological tumor graduation which considers (among other items) the number of mitotic figures per field ${ }^{18}$.

A precise identification of recurrent chromosomal abnormalities in malignant cells provides opportunities of improving diagnosis and prognosis of neoplastic diseases ${ }^{3}$. It has been established through cytogenetic studies that mammary, stomach, colon and brain tumors exhibit complex chromosomal alterations associated with advanced stages of these malignant diseases ${ }^{17}$. 
Many tumors are characterized by the presence of marker chromosomes which are much altered as a consequence of multiple breaks ${ }^{24}$. Fragile chromosomal sites are specific areas susceptible to gaps or breaks, they are inheritable ${ }^{8}$ and they could indicate regions of genome of major instability.

Canine mammary neoplasms are very frequent in the north-east region of Argentina and remarkably most of them are malignant. There have been many studies on this subject conducted in this region, primarily on clinical, cytological and histopathological aspects, however, no study was found on cytogenetic characteristics. Therefore, this work focused on researching recurrent and recognizable chromosomal abnormalities of neoplastic cells from different canine mammary tumors with the objective of contributing to the better understanding and knowledge of the disease. An additional objective was to evaluate the possibility of incorporating this type of analyses to routing diagnostic procedures to help physicians with diagnoses and prognosis of their patients.

\section{MATERIAL AND METHODS}

The study included spontaneous mammary tumors from 11 female dogs between 3 and 12 years old. Cytological and histological diagnosis were performed according to the histological classification of mammary tumors of the dog and the cat ${ }^{15}$. Slides were prepared following classical histological technique, and stained with hematoxylin and eosin.

Samples for cytogenetic studies were taken by "fine needle punction" a variant of "fine needle aspiration" ${ }^{1,5}$, using disposable 40 x 8 needles. In addition small tumor fragments were obtained from surgical specimens, before its fixation in formol. Chromosomes preparations were done according with the Foresti technique ${ }^{9}$.

Briefly, the tumor samples were first dissociated in Hank's solution and the cellular suspension was incubated for 30 minutes at $37^{\circ} \mathrm{C}$, after which one drop of colchicine $(0.0125 \%)$ was added. The material was centrifuged for 10 minutes at $900 \mathrm{rpm}$, the cellular pellet was resuspended in a hypotonic solution of $\mathrm{KCl}(0.075 \mathrm{M})$, and a second period of incubation for 25 minutes at $37^{\circ} \mathrm{C}$ was followed by fixation in methanol and acetic acid. Three drops of this solution were placed on slides and stained with $10 \% \mathrm{Gi}$ emsa solution in Sørensen's phosphate buffer ( $\mathrm{pH} 8.0)$ for 5 minutes.

Nucleolar organizing regions (NOR) were identified by silver staining following a modified Howell and Black technique ${ }^{13}$ using a solution of one drop of distillated water, one drop of jelly and two drops of $50 \%$ aqueous silver nitrate, by slide; and incubating for 3 minutes at $60^{\circ} \mathrm{C}$ in wet chamber. The metaphases were photographed with Infinity 1 Digital Kit attached to an Olympus BX41 microscope and then analyzed with the image analyzer program Image ProPlus 5.1. The examination consisted of chromosome count, screening and identification of chromosomal alterations. The best quality metaphases and those that showed peculiarities were selected to illustrate this paper.

\section{RESULTS}

Cytogenetics of the canine females. Canis familiaris female's karyotype has a chromosome number of 78 , consisting of 39 chromosome pairs of which 38 are autosomes (acrocentric) and the remaining pair are sex chromosomes XX (metacentric) (Figure 1A). Silver nitrate stain show up to 8 chromosomes with positive NOR located in the distal region of the long arm of acrocentric chromosomes (Figure 1B).

Tumor's cytogenetics. Fourteen tumors from the 11 female dogs were studied. They were diagnosed as simple and complex carcinomas, and carcinomas in mixed tumor, according to the histological classification previously cited. Metaphases were detected in 8 tumors' samples from 5 patients. Among them, no more than 5 tumors' samples showed chromosomal breaks and/or gaps (B and/or G) (Table 1).

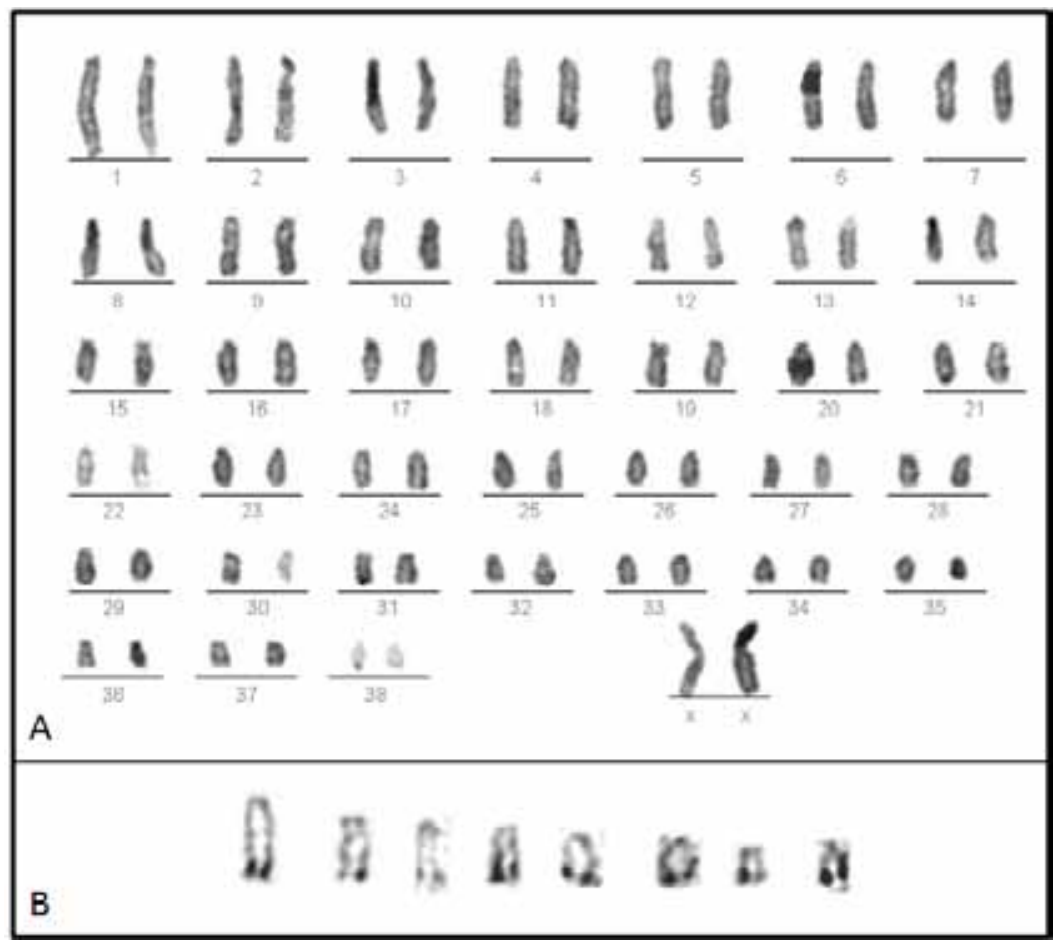

Figure 1. A. Female dog cariotype, 38 autosomal pairs and sex chromosomes. B. Nucleolar organizing regions (NOR), stained at the distal positions of the long arms. 
Table 1. Summary of cases.

\begin{tabular}{lcccccc}
\hline case & $\mathrm{HT}$ & $\mathrm{N}^{\circ}$ & $\mathrm{B} / \mathrm{G}$ & metaph. & chrom. & average \\
\hline 1 & $\mathrm{SC}$ & 6 & $0(0 \%)$ & 0 & 0 & 0 \\
2 & $\mathrm{CMT}$ & 1 & $0(0 \%)$ & 0 & 0 & 0 \\
3 & $\mathrm{SC}$ & 3 & $0(0 \%)$ & 0 & 0 & 0 \\
4 & $\mathrm{CC}$ & 29 & $22(76 \%)$ & 41 & 1.41 & 1.52 \\
5 & $\mathrm{CC}$ & 19 & $12(63 \%)$ & 31 & 1.63 & 2 \\
6 & $\mathrm{CC}$ & 5 & $1(20 \%)$ & 1 & 0.20 & 0.20 \\
7 & $\mathrm{CC}$ & 7 & $7(100 \%)$ & 16 & 2.29 & 3.14 \\
8 & $\mathrm{SC}$ & 4 & $3(75 \%)$ & 4 & 1 & 1 \\
total & & 74 & $45(61 \%)$ & 93 & 1.26 & 1.47 \\
\hline
\end{tabular}

HT: histological type, $\mathrm{N}^{\circ}$ : number of metaphases, metaph.: metaphases showing breaks (B) and/or gaps (G), chrom.: average number of chromosomes showing $\mathrm{B}$ and/or $\mathrm{G}$, average: average number of $\mathrm{B}$ and/or $\mathrm{G}$ per metaphase, $\mathrm{SC}$ : simple carcinoma, CTM: carcinoma in mixed tumor, CC: complex carcinoma.

The number of chromosomes showing abnormalities ranged from 1 to 5 , with an average of 1.26 per metaphase. $\mathrm{B}$ and/or $\mathrm{G}$ aberrations by metaphases ranged from 1 to 8 (Figure 2A-E) with an average of 1.47. The absolute values and means are presented in Table 1.

The aberrations were located on sex chromosomes and autosomes of different sizes. Both breaks and gaps were observed in the same metaphase over autosomes and $\mathrm{X}$ chromosomes, located at proximal, interstitial and distal positions of chromosomal long arms. Many metaphases showed more than one aberration on the same chromosome. For example, small autosomes presenting double breaks on the same chromatid and others showing gaps in both chromatids can be appreciated in Figure 2 B and D. Also, a double break was observed on one $\mathrm{X}$ chromosome long arm (Figure 2F). $\mathrm{B}$ and/or $\mathrm{G}$ on the sex chromosomes were seen in the $13.33 \%$ of metaphases with chromosomal aberrations, while the $97.77 \%$ of affected metaphases showed damage on the autosomes.

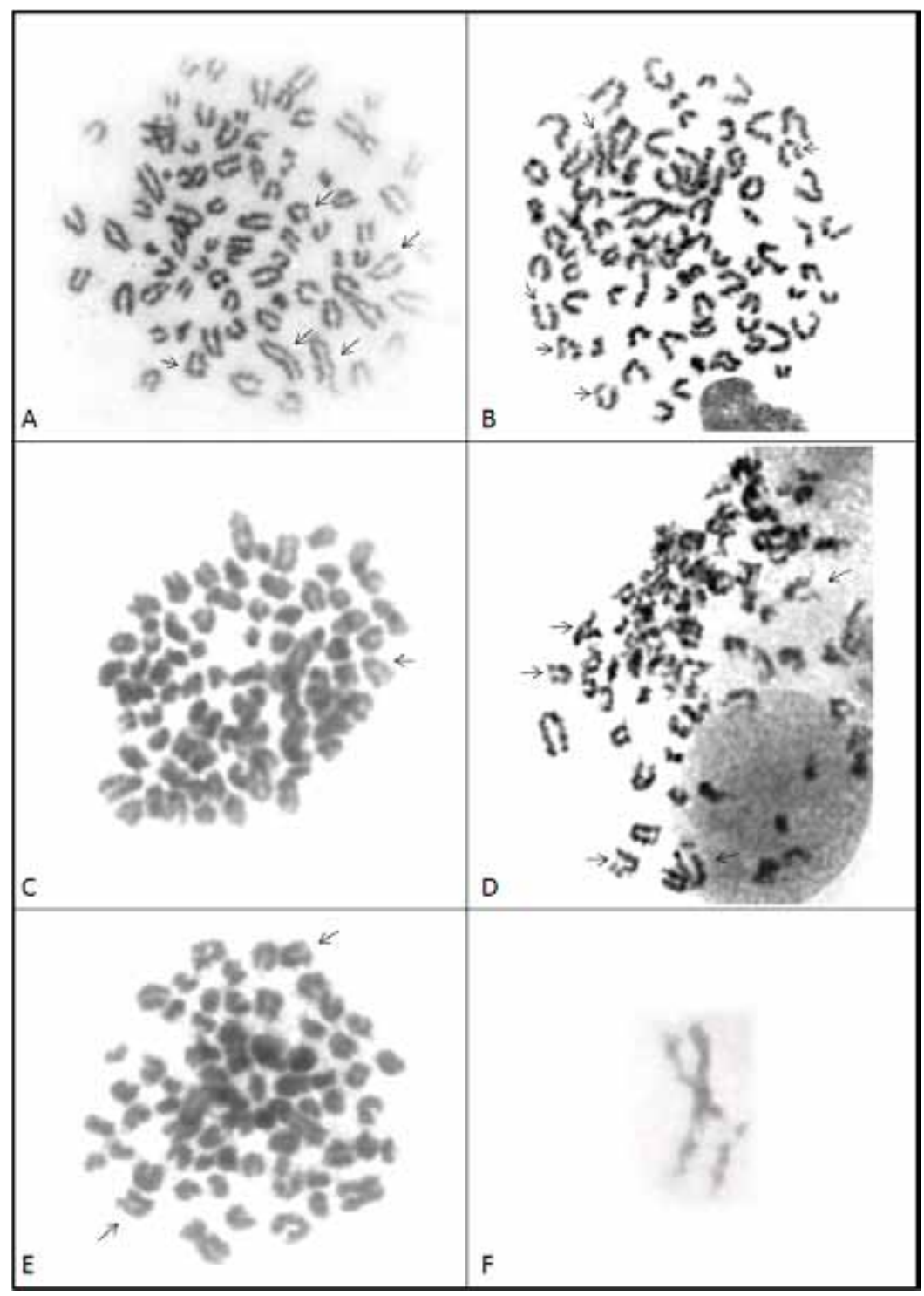

Figure 2. A-E. Methaphases showing chromosomes carrying breaks and/ or gaps, cases 4 to 8 respectively, the arrows indicate the affected chromosomes. F. Sex chromosome with a double break on the long arm.

\section{DISCUSSION}

It has been suggested that chromosome breaks and gaps are the first events of chromosomal instability. In humans beings and other mammalian, chromosome fragility has been observed in many diseases with severe phenotypic effects such as cancer, fragile $\mathrm{X}$ syndrome and fertility alterations ${ }^{22,}{ }^{23}$. With respect to cancer, authors suggest that fragile sites are more prone to breakage and chromosomal rearrangements in somatic cells leading to the possible activation of oncogenes or inactivation of tumor suppressor genes related with cancer pathogenesis ${ }^{8}$.

Fragile sites are usually found in genes involved in tumorigenesis mapped with multiple oncogenes, and more than half of all cancer specific sites of breaks and recurrent translocations. It has been statistically demonstrated that most of chromosomal bands containing fragile sites are involved in specific structural alterations in malignant diseases ${ }^{11,26}$. Some authors established the presence of fragile sites on the $\mathrm{X}$ chromosomes of Canis familiaris, studying the nucleus of malignant neoplasms by molecular techniques ${ }^{14}$.

In this study the B and/or G observed affected autosomes and sex chromosomes, occurring at proxi- 
mal, interstitial and distal positions on the long arms of these chromosomes. They appeared in an average number of 1.47 per metaphase. It was possible to identify chromosomes with double $\mathrm{B}$ and/or $\mathrm{G}$ on the same chromatid, as also B and/or $\mathrm{G}$ in both sister chromatids. The $61 \%$ of metaphases showed altered chromosomes, while the average number of them per metaphase was 1.26 .

NOR showed the same autosomal terminal location reported by other authors ${ }^{19-21}$, however, no positive bands were observed on sex chromosomes. The data confirmed these structures as secondary constrictions and differentiated them from the other structures described here as B and/or G.

Chromosomal aberrations were found in 5 of the 14 malignant neoplasms studied here. These tumors were diagnosed as complex and simple carcinomas. According to classical bibliography the latter type has a worse prognosis than the former one ${ }^{15}$, however, here chromosomal alterations were more frequent in complex carcinomas. The chromosome B and/or G in these tumors could be considered as indicators of malignancy and poor prognosis for patients with such diseases ${ }^{2,16}$, but not as histological types' diagnostic markers.

The majority of malignant solid tumors exhibit a complex pattern of chromosomal abnormalities, rarely showing any direct association with specific morphological or prognostic subgroups ${ }^{12}$. Further, these alterations may not necessarily be the cause of neoplasm development, but may be the physical manifestation of mutations affecting genes involved in the process 2,6 , ${ }^{25}$. Also, they could be contributing to carcinogenesis if occurring close to genes involved in tumorigenesis ${ }^{11,26}$.

In this paper very few tumor samples have been analyzed, and the histological type more frequently found (complex carcinoma), showed most of the chromosomal aberrations. Due to time limitations this study was conducted over a one year period, with no follow up of patient evolution after surgery. Other studies point out that chromosomal alterations associated with carcinomas result in a poor prognosis for the patient and are considered as unfavorable factors in these diseases ${ }^{2,16}$. It would be therefore expected that female dogs showing chromosomal aberrations in this study had a high recurrence probability and a short life span.

Neoplasms final evolution is very difficult to predict due to it dependency on many diverse biological factors, as particular neoplastic cells characteristics and patient's conditions. This lead to the conclusion that it would be impossible to make a prognosis taking just one factor into account, hence it would be more reliable to consider a wide group of known and proven factors in order to create an accurate biological prognostic profile ${ }^{7}$.

It is emphasized that chromosomal studies must be taken into account, for any type of malignancy, in order to obtain better information about the spectrum of aberrations and identify specific recurrent chromosomal abnormalities during the malignant transformation process ${ }^{16}$. They also indicate that it would be valuable to correlate these findings with histopathological studies with the purpose of achieving a better diagnosis and prognosis of patients with different malignancies.

It is concluded that this type of cytogenetic study is a supportive method in the prediction of life expectancy of patients affected by mammary tumors since the occurrence of chromosomal abnormalities in cancer is associated with poor prognosis. We encourage the inclusion of cytogenetic studies in the diagnosis routine, aimed to improving tumors descriptions critical in making more accurate diagnosis and prognosis.

Acknowledgments. Authors would like to express their sincere thanks to Dr. Patricia Koscinczuk and Dr. Graciela I. Lavia for their collaboration in this study.

\section{REFERENCES}

1. Akhtar M, Ashraf A, Huq M, Faulkner C. 1989. Fineneedle biopsy: comparison of cellular yield with and without aspiration. Diag Cytopathol 5: 162-165.

2. Assumpção PP, Seabra DA, Leal FM, Guimarães CA, Calcagno QD, Khayat SA, Smith CM, Burbano RR. 2006. Chromosome instability in carcinomas. Int $J$ Morphol 24: 335-338.

3. Breen M. 2008. Canine cytogenetics-from band to basepair. Cytogenet Genome Res 120: 50-60.

4. Brodey RS, Goldschmidt MH, Roszel JR. 1983. Canine mammary gland neoplasms. J Am Anim Hosp Assoc 19: 61-90.

5. Cajulis R, Sneige N. 1993. Objective comparison of cellular yield in fine-needle biopsy of lymph nodes with and without aspiration. Diag Cytopathol 9: 43-45.

6. Casper AM, Nghiem P, Arlt MF, Glover TW. 2002. ATR regulates fragile site stability. Cell 111: 779-789.

7. Díez M, Pérez J, Martín A. 2001. Marcadores tumorales de valor pronóstico en adenocarcinomas de colon y recto. Gastroenterol Integr 2: 207-221.

8. Escribano GR, Castillo ST, Daher VN, Salazar SC, Tobella LP. 2009. Principales factores que producen fragilidad cromosómica transitoria en los pacientes referidos para estudio citogenético. Rev Hosp Clin Univ Chile 20: 20-27.

9. Foresti F, Almeida C, Almeida LA. 1993. A method of chromosome preparations from large fish specimens using in vitro short-term treatment with colchicines. Experientia 49: 810-814.

10. Foster R. 2007. Female Reproductive System. In: Pathologic Basis of Veterinary Disease (McGavin MP, Zachary JF ed.), 4th ed., Elsevier, Beijing, p. 1263-1315.

11. Fundia A, Larripa I. 1996. Participación de los sitios frágiles en cáncer. Medicina 56: 727-732.

12. Gisselsson D. 2001. Chromosomal instability in cancer: causes and consequences. Atlas Genet Cytogenet Oncol Haematol 5: 237-244.

13. Howell WM, Black DA. 1980. Controlled silver-staining of nucleolus organizer regions with a protective colloidal developer: a 1-step method. Experientia 36: 1014-1015. 
14. Milne BS, Hoather T, O'Brien PC, Yang F, Ferguson MA, Dobson J, Sargan D. 2004. Karyotype of canine soft tissue sarcomas: a multi-color, multi-species approach to canine chromosome painting. Chromosome Res 12: 825835.

15. Misdorp W, Else RW, Hellmen E, Lipscomb TP. 1999. Histological Classification of Mammary Tumors of the Dog and the Cat, 2nd ed., vol. 7. Publ. by The Armed Forces Institute of Pathology with the WHO, Washington, p. 58.

16. Muñetón CM, Ramírez JL. 2002. Revisión de tema citogenética de tumores sólidos. IATREIA 15: 86-95.

17. Muñetón CM, Vázquez EM, Durango NE, Martínez J, Ramírez J. 2004. Cytogenetic analyses of eight solid tumors and correlation with histopathologic finding. $\mathrm{Pa}$ tología (México) 42: 65-72.

18. Ochoa JE, Pedraza LN, Ciuoderis KA. 2009. Carcinoma complejo de glándula mamaria, acantoma queratinizante infundibular y mastocitoma tipo III en un canino. Rev MVZ Córdoba (España) 14: 1844-1855.

19. Pienkowska A, Switonski M. 1998. Chromosomal localization and activity of nuclear organizer regions in the dog. Genet Sel Evol 30: 79-84.
20. Rønne M, Poulsen BS, Shibasaki Y. 1991. NOR association in Canis familiaris. Genet Sel Evol 23: 191-195.

21. Shibasaki Y, Poulsen BS, Johansen B, Rønne M. 1990. Banding studies in Canis familiaris. II. Nucleolar organizer regions and NOR association. In Vivo (Greece) 4: 243246.

22. Slota E, Danielak B, Pietrasszewska J, Kozubska A. 2000. Preliminary identification of the fragile $X$ in two crossbred cows. Veterinarni Med (Czech) 45: 308-310.

23. Sutherland G, Baker E, Richards R. 1998. Fragile sites still breaking. Trends Genet 14: 501-506.

24. Therman E, Susman, M. 1993. Human Chromosomes Structure, Behavior and Effects, 3rd ed., Springer, Berlín, $376 \mathrm{p}$.

25. Van Gent DC, Hoeijmakers JH, Kanaar R. 2001. Chromosomal stability and the DNA double-stranded break connection. Nature 2: 196-206.

26. Yunis JJ, Soreng L. 1984. Constitutive fragile sites and cancer. Science 226: 1199-1204.

\section{SJR Sclmaso Journal \& Country Rank}

\section{Powered by Scopus"}

\section{Índice de impacto de Revista Veterinaria}

Noticias de Scimago Research Group (Scimago Journals \& Country Ranks, Scopus-Elsevier) comunican que la publicación de nuestra casa, Revista Veterinaria, continúa registrando índice de impacto. El índice SJR mide la influencia científica (impacto) del artículo de una revista, expresando cuán importante es el "artículo promedio" de la publicación en la discusión científica global (sistema Thomson Reuters).

Para nuestra revista, tal indicador había sido de 0,03 en 2008 y continuó en 2009, 2010 y 2011 exhibiendo ahora un nivel promedio de 0,05 (media de 3 últimos años). Asimismo, surge para nuestra publicación un sostenido descenso del indicador que relaciona "citas versus autocitas", demostrando que los autores de los artículos están abandonando la práctica de citar sus propias publicaciones anteriores.

Por último, se advierte que según este portal, nuestra "Revista Veterinaria" continúa siendo la única publicación de esta rama de la ciencia que posee índice de impacto en Argentina. Para el resto del cono sur tal distinción recae en Brasil (siete revistas), Chile (una revista), Colombia (una revista) y Venezuela (una revista). No registran índice de impacto las revistas de veterinaria de Bolivia, Paraguay, Uruguay, Perú y Ecuador. 